\title{
Spatial analysis of the potential demand for public transport in the city of Jeddah, Saudi Arabia
}

\author{
M. Aljoufie \\ Department of Urban and Regional Planning, \\ Faculty of Environmental Design, King Abdulaziz University, \\ Saudi Arabia
}

\begin{abstract}
Jeddah's rapid urban growth over the last four decades has caused significant and critical changes in travelling patterns and the modes of transportation used throughout the city. The share of daily trips by public transport has significantly decreased from $19 \%$ in 1970 to $2.3 \%$ in 2007 . The promotion of efficient public transport has received a high level of political interest in Saudi Arabia and it is a major issue in Jeddah. It is one of the main policy recommendations of both the 2005 Jeddah structure plan and the 2009 Jeddah strategic plan. However, the analysis of potential demand for public transport in Jeddah has received a little attention. This paper analyzes the deficiencies of the current public transport system in Jeddah and identifies the potential demand for public transport using GIS based approach. The results show that $50 \%$ of the Jeddah population have low or no access to the current public transport system, which is characterized by deficiency and poor condition of the infrastructure. Results also reveal both a dispersed and clustered patterns of high need for public transport in Jeddah. The results of this study facilitate the identification of potential demand for public transport in Jeddah.

Keywords: public transport, transport need, indicators, demand, spatial analysis, GIS, Jeddah city.
\end{abstract}




\section{Introduction}

Rapid urban growth causes enormous and continued challenges to many cities in both developing and developed countries. A rapidly growing population, denser use of space and increased motorization cause significantly more traffic and high dependence on private vehicle, resulting in congestion and a wide range of other effects, such as air pollution, greenhouse gas emissions and economic losses $[1,2]$.

Jeddah, the second largest city in Saudi Arabia, has witnessed a rapid urban growth over the last four decades. Jeddah's population grew rapidly, from 147,900 in 1964 to $3,430,697$ in 2010 and urban mass has expanded dramatically from 18,315 hectare in 1964 to 54,175 hectare in 2007 [2]. In addition, transportation infrastructure increased rapidly from $101 \mathrm{~km}$ in 1964 to $826 \mathrm{~km}$ in 2007.

This has caused significant changes in travel behaviour and the modes of transportation used throughout the city. Urban sprawl, lack of integrated planning framework and dramatic land use changes have caused a significant impact on the daily share of travel modes [2]. The share of non-car daily trips has decreased dramatically. Daily trips with public transportation decreased from $19 \%$ of all travel modes in 1970 to $2.3 \%$ in 2007 [2]. The share of other modes, including cycling and pedestrian trips, has decreased from $31 \%$ in 1970 to $4.6 \%$ in 2007 [2]. As Jeddah's urban area expanded dramatically in different directions and the compactness of the city reduced, the travel behaviour has been affected and the daily share of car trips has been stimulated. In fact, the share of daily car trips increased from $50 \%$ in 1970 to $96 \%$ in 2012. Notwithstanding the significance of the effects of spatial expansion on travel mode changes, urban development and transportation policies in Jeddah have induced the car use. Enormous land subdivision throughout the city, an arterial gridiron pattern of street networks and lack of policy to stimulate public transport and other non-car modes further contributed to this [2]. This has coincided with poor public transport coverage and service.

This has result in high mobility levels throughout the city wherein congestion is common on Jeddah's streets in the morning and evening peak periods and in non-peak hours $[3,4]$. The average speeds on the highways and the main roads is decreasing, and traffic safety is declining, while transportation emissions and average trip durations are increasing $[2,4]$.

To confront theses challenges, encouragement of effective public transport is vital. In fact, public transport is becoming a more acceptable alternative to the private automobile and experiencing greater use by a wider socioeconomic range of people, due to higher personal transport costs, environmental concerns, and increasing congestion in urban areas [5]. In Saudi Arabia, the promotion of efficient public transport has received a high level of political interest it is a major concern in Jeddah. It is highly emphasized in the National Transport Strategy and it is one of the main policy recommendations of both the 2005 Jeddah structure plan and the 2009 Jeddah strategic plan [6]. However, the 
analysis of public transport provision and demand has received a little attention in Jeddah city.

This paper attempts to analyze the potential demand for public transport in Jeddah using a GIS based approach. Initially, this paper analyzes the spatial deficiencies of the current public transport system in Jeddah. Then it strives to identify and spatially analyze the potential demand for public transport in Jeddah.

\section{Methodology}

\subsection{Study area}

Jeddah is the second largest city in the Kingdom of Saudi Arabia. Jeddah is located on the West coast of the Kingdom in the middle of the eastern shore of the Red Sea and surrounded by the plains of the Tahoma in the east (figure 1).

b)

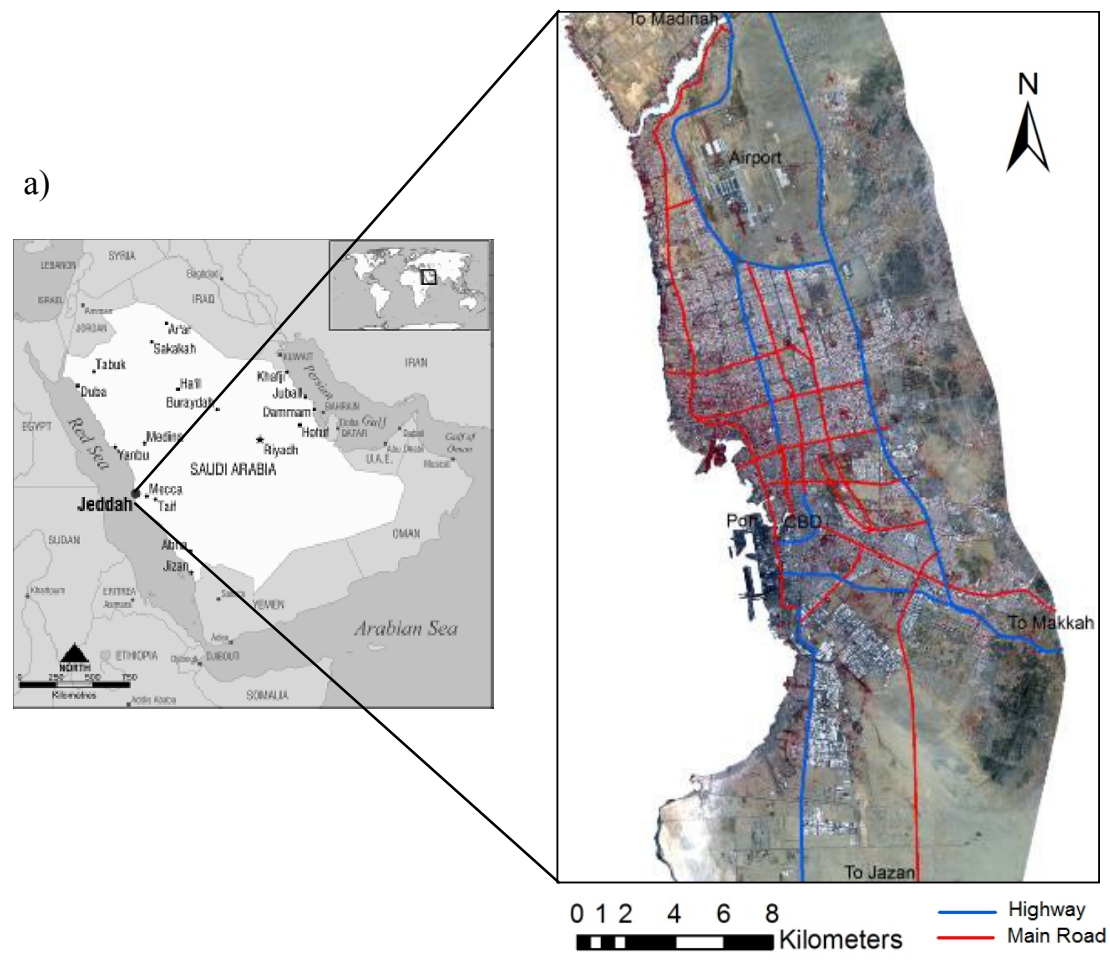

Figure 1: a) Geographic location of Jeddah (source: en.wikipedia.org/ wiki/Jeddah), b) Jeddah city. 
The city of Jeddah has witnessed a dramatic increase in population, due to out-migration from villages and suburbs to the city in search of jobs and a better living. Jeddah is car dominated with residents using private automobiles for $96 \%$ of trips [7]. The challenges of rapid urban expansion, population growth and traffic congestion are currently predominant issues in Jeddah's planning and governance. The study area of this study covers the large extent of the urban area in Jeddah city.

\subsection{Analysis of the current public transport system in Jeddah}

The share of daily car trips in Jeddah has dramatically increased from $50 \%$ in 1970 to $96 \%$ in 2012. Public transport, walking and cycling, jointly represent only $4 \%$ of the total trips in the city [7]. Two main systems represent public transport in Jeddah: (1) The Saudi Arabian Public Transport Company (SAPTCO), which operates the regulated bus systems; (2) Unregulated Coaster buses services operated by individuals.

The SAPTCO regulated bus system consists of approximately 90 buses. It is operated on eight main service lines that cover in total a distance of $150 \mathrm{~km}$, figure 2. The unregulated coaster buses are operated in 10 main service lines that cover in total a distance of $160 \mathrm{~km}$, figure 3. This service includes 1737 old coaster buses (19 to 21-passenger capacity), 1972-1982 models, and only 5\% are valid to operate [8].

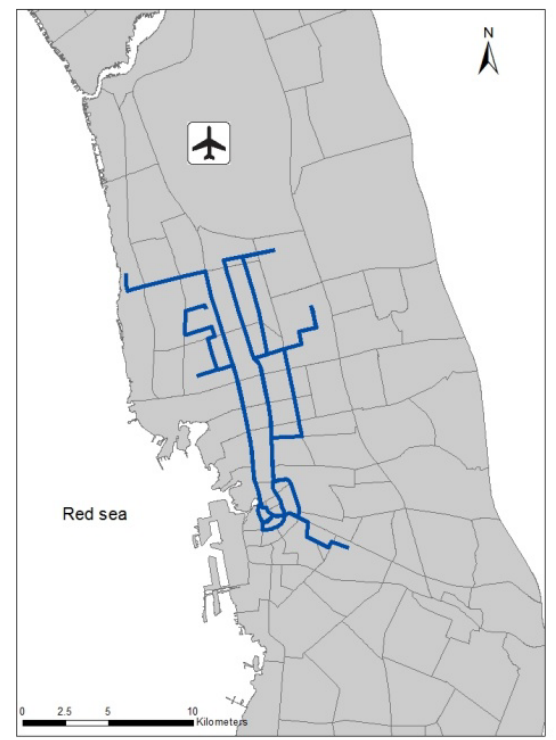

Figure 2: SAPTCO service lines.

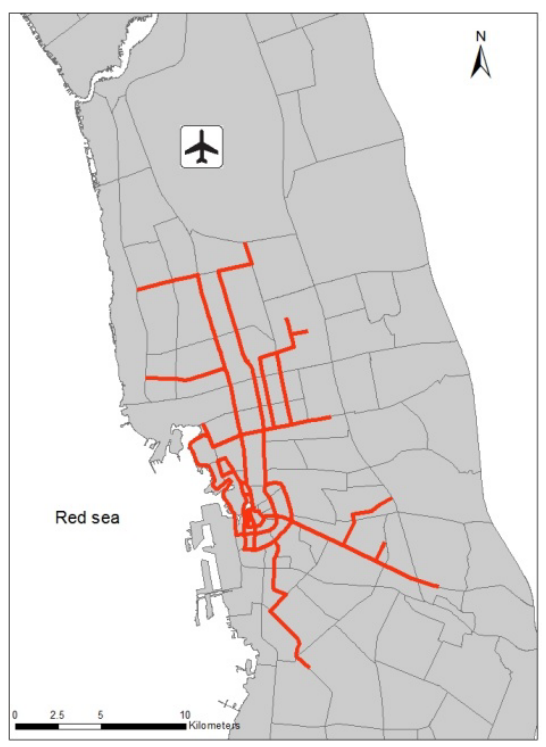

Figure 3: Unregulated coaster buses service lines. 
To measure the spatial deficiency of the current public transport system in Jeddah, spatial proximity analysis was conducted. Buffer analysis was used to measure the proximity of people to the service (routes). However, a selection of an appropriate walking distance was vital. Guidelines often use $400 \mathrm{~m}$, or multiples such $800 \mathrm{~m}$, as key distances in network and service planning [9]. Armstrong-Wright and Thiriez [10] recommend that the walking distance should be between 300-500 $\mathrm{m}$ and the maximum distance should not exceed $800 \mathrm{~m}$. Accordingly, two buffer distances of the service routes were considered $400 \mathrm{~m}$ and $800 \mathrm{~m}$. Subsequently, districts population density was overlapped with the created buffer zones. Then the percentage of social inclusion of the current public transport was calculated.

\subsection{Spatial analysis of the potential public transport demand in Jeddah}

In essence, various factors influence the demand for public transport. Murray and Davis [11] developed an index to measure the potential need for public transport based on characteristic indicators of spatial units. Three indicators were used, namely: the household income, unemployment rates, and average family size. A weighting approach that combines these indicators was used to evaluate the public transport needs for each zone within the study area.

Currie $[12,13]$ proposed a transport needs index at district level. This index encompassed indicators for transport needs, namely: adults without cars, persons aged over 60 years, persons on a disability pension, low-income households, adults not in the labour force, students and persons 5 to 9 years.

Yao [14] used a composite need index to measure the relative potential demand for public transport in a spatial unit. Three groups of factors for public transit ridership for commuting trips in Atlanta were identified. The first group was the land use characteristics which include: population density, employment rate (percentage of people who have jobs), job density (total jobs in the TAZ divided by the area of the TAZ), average number of jobholders per household, and percentage of home workers. The second group was the socioeconomic characteristics which encompass: income and car ownership. The third group was the network structure which includes the density of public transit stops in the TAZ.

In view of that and based on data availability, five indicators were selected for the analysis. Table 1 depicts the selected indicators, which were based on a review of available socioeconomic data and related to transport need. Population density, car ownership unemployment and poverty (low-income households) indicators at district level were considered. In addition to that widows and divorced women indicator was developed. This indicator is designed to measure the need of important group of Jeddah society that have no direct transport means. This indicator is critical in analyzing transport need and potential demand. It is defined as the percentage of widows and divorced women per district.

A consistent weighting approach that evaluates the public transport needs for each district within the study area was used. Each indicator was classified into three weights as follows: 
- High: high need for public transport,

- Medium: medium (moderate) need for public transport, and

- Low: low need for public transport.

An absolute need scores from 3 to $1($ High $=3$, Medium $=2$ and Low $=1)$ were used in the weighting to standardize the value of indicators. Weight 3 represents districts with high social need for public transport while weight 1 represents districts with low social need for public transport. The weightings of each indictor into the three classes were based on the available data and sources $[15,16]$.

Table 1: $\quad$ Selected indicators and weight.

\begin{tabular}{|c|c|c|c|}
\hline Indicator & Description & Source & Weight \\
\hline Population density & $\begin{array}{l}\text { Person/hectare per } \\
\text { district }\end{array}$ & Census 2010 & $\begin{array}{l}\text { (3) High : } \quad>150 \text { person per } \\
\text { hectare } \\
\text { (2) Medium : } 75-150 \text { person per } \\
\text { hectare } \\
\text { (1) Low: } \quad<75 \text { person per } \\
\text { hectare }\end{array}$ \\
\hline Car ownership & $\begin{array}{l}\text { Number of car per } \\
100 \text { persons per } \\
\text { district }\end{array}$ & $\begin{array}{l}\text { Jeddah } \\
\text { Urban } \\
\text { Observatory } \\
2009^{*}\end{array}$ & $\begin{array}{l}\text { (3) High: } \quad<20 \text { car } / 100 \\
\text { persons } \\
\text { (2) Medium : } 75-150 \text { person per } \\
\text { (1) Low: } \quad<75 \text { person per } \\
\text { hectare }\end{array}$ \\
\hline Unemployment & $\begin{array}{l}\text { \% of unemployed } \\
\text { persons per } \\
\text { district }\end{array}$ & $\begin{array}{l}\text { Jeddah } \\
\text { Urban } \\
\text { Observatory } \\
2009^{*}\end{array}$ & $\begin{array}{lc}\text { (3) High : } & >15 \% \\
\text { (2) Medium : } 9-15 \% \\
\text { (1) Low: } \quad<8 \%\end{array}$ \\
\hline Poverty & $\begin{array}{l}\% \text { of poor } \\
\text { families per } \\
\text { district }\end{array}$ & $\begin{array}{l}\text { Jeddah } \\
\text { Urban } \\
\text { Observatory } \\
2009^{*}\end{array}$ & $\begin{array}{lr}\text { (3) High : } & >30 \% \\
\text { (2) Medium : } & 11-30 \% \\
\text { (1) Low: } \quad<10 \%\end{array}$ \\
\hline $\begin{array}{l}\text { Widows and } \\
\text { divorced women }\end{array}$ & $\begin{array}{l}\% \text { of widows and } \\
\text { divorced women } \\
\text { per district }\end{array}$ & $\begin{array}{l}\text { Jeddah } \\
\text { Urban } \\
\text { Observatory } \\
2009^{*}\end{array}$ & $\begin{array}{ll}\text { (3) High : } & >10 \% \\
\text { (2) Medium : } & 6-10 \% \\
\text { (1) Low: } & <5 \%\end{array}$ \\
\hline
\end{tabular}

*Jeddah Urban Observatory (2009). Districts GIS Indicators, Jeddah Urban Observatory, Jeddah Municipality.

Subsequently, a composite need indicator of assessing public transport need was developed. It was generated by adding the scores for each indicator together as in the following:

$$
\mathrm{CNI}=\sum \mathrm{PdI}+\mathrm{CI}+\mathrm{UnI}+\mathrm{PI}+\mathrm{WI}
$$

where $\mathrm{CNI}$ is the composite need indicator, PdI is the standardized population density indicator, CI is the standardized car ownership indicator, UnI is the 
standardized unemployment indicator, PI is the standardized poverty indicator and WI is the standardized widows and divorced women indicator.

The composite need index was standardized between 3 and 15 for all districts in the analysis in order to obtain need scores. Value 3 represents districts with low social need for public transport while value 15 represents districts with low social need for public transport. To quantify the composite need, the results were then divided into three groups as follows:

- High: from 11 to15.

- Medium: from 7 to 10 .

- Low: from 5 to 6 .

\section{Results and discussion}

\subsection{Current public transport system in Jeddah}

In essence, transport system provides mobility for people to reach places for different activities. Poor transport provision and accessibility can lead to social exclusion and severance of communities. Based on proximity analysis of the current public transport service lines, $41 \%$ of the population in Jeddah are within a distance of less than $400 \mathrm{~m}$ while $51 \%$ are within a distance less than $800 \mathrm{~m}$. Thus, there is a social exclusion in the current public transport system in Jeddah. Around $50 \%$ of the Jeddah population have low or no access to public transport system. It is noteworthy that low to medium income groups in Jeddah represent $49 \%$ of the population [16], and $10.5 \%$ of Jeddah families have no car [16].

Although $41-51 \%$ of Jeddah population are proximate to the current public transport service lines, few use public transport. In 2007, public transport share only $2.3 \%$ of the total daily trips in Jeddah. However, it must be noted that, bad conditions, unscheduled services, deficient infrastructure are common problems of the current public transport in Jeddah. Accordingly, there is a high captivity to private vehicles as people in Jeddah have no choice but to drive their own private cars for daily movement due to the low accessibility to public transport and the poor condition of the infrastructure, including the buses.

\subsection{Potential public transport demand in Jeddah}

The indicators of public transport need in Jeddah are determined by district. Table 2 and figures 4-9 show the results of the spatial analysis of the developed transport need indicators. Population density indicator depicts high transport need in different districts throughout Jeddah (figure 4). It is noted that high and medium needs are dominant with this indicator as compared with low need which reflected by the population, as shown in table 2 .

Figure 5 shows the spatial distribution of the absolute scores of car ownership indicator. The districts, which show high public transport need, are found in the city centre. The population with high and medium need are dominant under this indicator as compared with population with low need (as indicated in table 2). It 
is noted that unemployment indicator, poverty indicator and widows and divorced women indicator exhibit a comparable population for high, medium and low need (as shown in table 2). However, the spatial distribution of absolute scores of these indicators differs. For the unemployment and poverty indicators the districts, which show high public transport need, are found in the city centre (figures 6 and 7). It is also noted that for these indicators, the districts, which show medium need, are distributed throughout Jeddah in a comparable pattern. Conversely, the widows and divorced women indicator depicts high transport need in different districts throughout Jeddah (figure 8). The districts, which show medium need, are distributed throughout Jeddah in dispersed pattern.

Table 2: No. of districts and population by transport need for each indicator.

\begin{tabular}{|c|c|c|c|c|c|c|c|c|c|c|c|c|}
\hline \multirow[b]{2}{*}{ Weight } & \multicolumn{2}{|c|}{$\begin{array}{l}\text { Population } \\
\text { density } \\
\text { indicator }\end{array}$} & \multicolumn{2}{|c|}{$\begin{array}{c}\text { Car } \\
\text { ownership } \\
\text { indicator }\end{array}$} & \multicolumn{2}{|c|}{$\begin{array}{c}\text { Unemployment } \\
\text { indicator }\end{array}$} & \multicolumn{2}{|c|}{$\begin{array}{l}\text { Poverty } \\
\text { indicator }\end{array}$} & \multicolumn{2}{|c|}{$\begin{array}{c}\text { Widows and } \\
\text { divorced women } \\
\text { indicator }\end{array}$} & \multicolumn{2}{|c|}{$\begin{array}{c}\text { Composite } \\
\text { need } \\
\text { indicator }\end{array}$} \\
\hline & Dist. & Pop. & Dist. & Pop. & Dist. & Pop. & Dist. & Pop. & Dist. & Pop. & Dist. & Pop. \\
\hline High & 13 & 853607 & 21 & 834142 & 15 & 487166 & 15 & 465934 & 9 & 447055 & 20 & 930331 \\
\hline Medium & 16 & 1181026 & 10 & 808026 & 12 & 957572 & 12 & 953789 & 19 & 1020423 & 24 & 1466380 \\
\hline Low & 29 & 650529 & 27 & 1042994 & 31 & 1240424 & 31 & 1265439 & 30 & 1217684 & 14 & 288451 \\
\hline
\end{tabular}

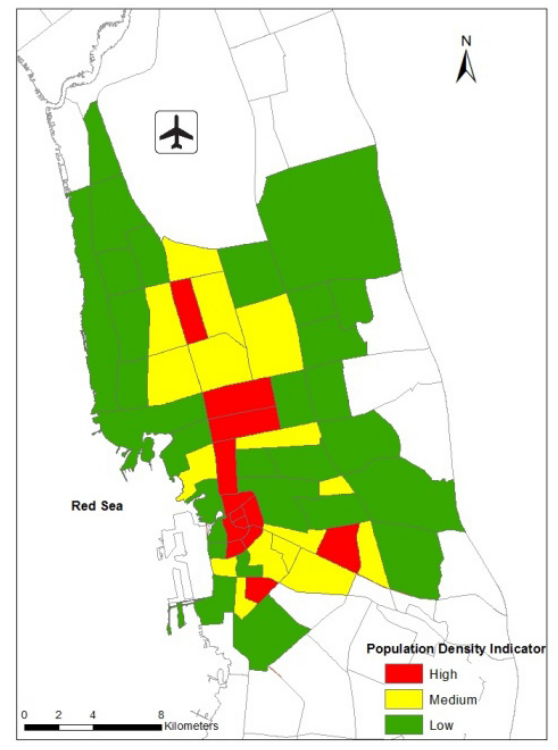

Figure 4: Population density indicator.

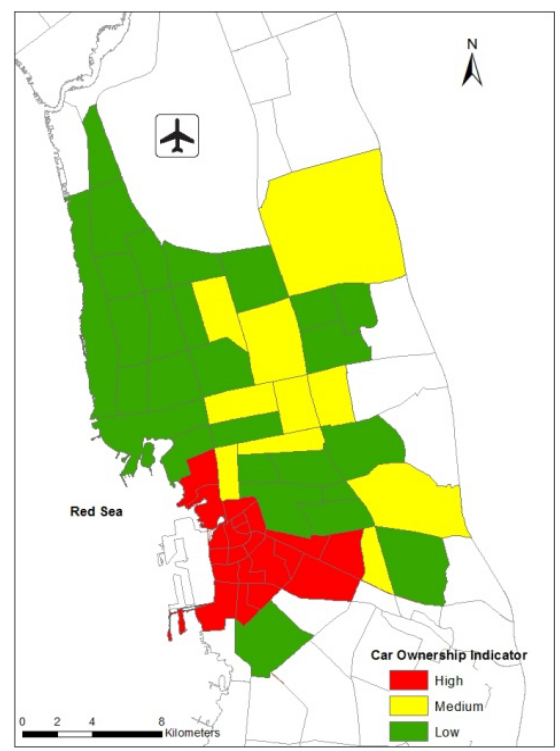

Figure 5: Car ownership indicator.

The result of composite need indicator, which combines all the considered five indicators, show both dispersed and clustered patterns of high need for public transport in Jeddah. It is found that districts with high need are concentrated and clustered in the city centre, while single districts are found at the north of the city centre (figure 9). Medium need also exhibit the clustered pattern of districts at the north and south of Jeddah city. It is noteworthy that 
high and medium need districts are dominant and spatially connected (figure 9). Almost $27 \%$ of Jeddah population are in high need for public transport while around $38 \%$ are in medium need for public transport (table 2).

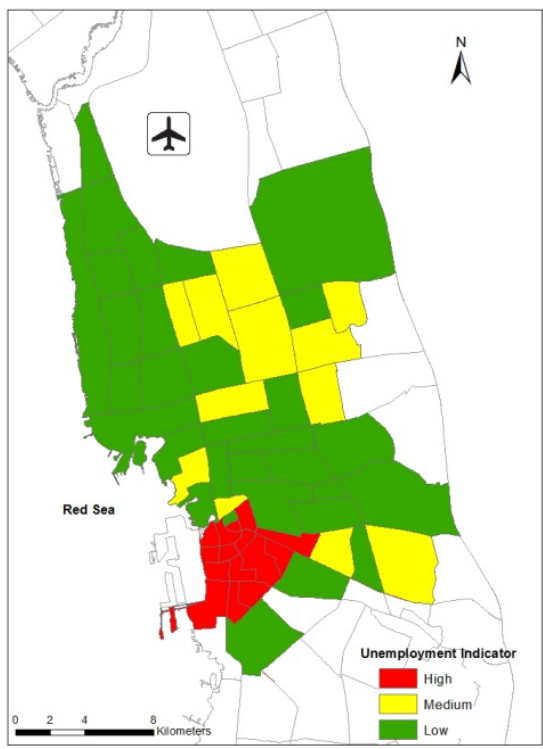

Figure 6: Unemployment indicator.

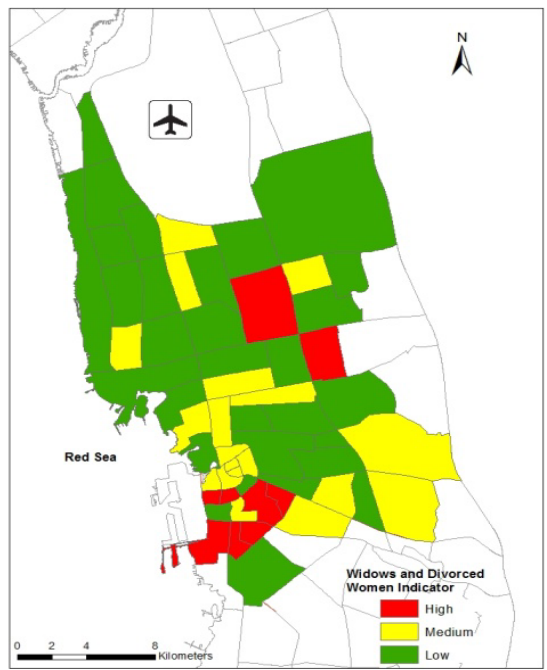

Figure 8: Widows and divorced women indicator.

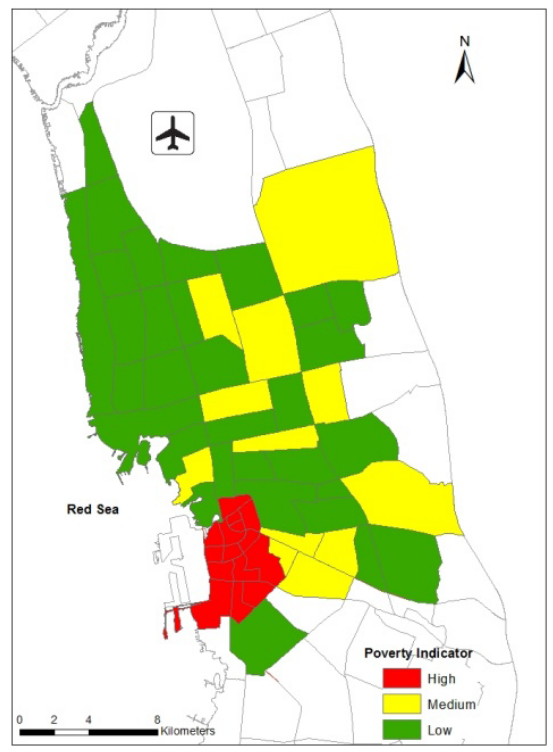

Figure 7: Poverty indicator.

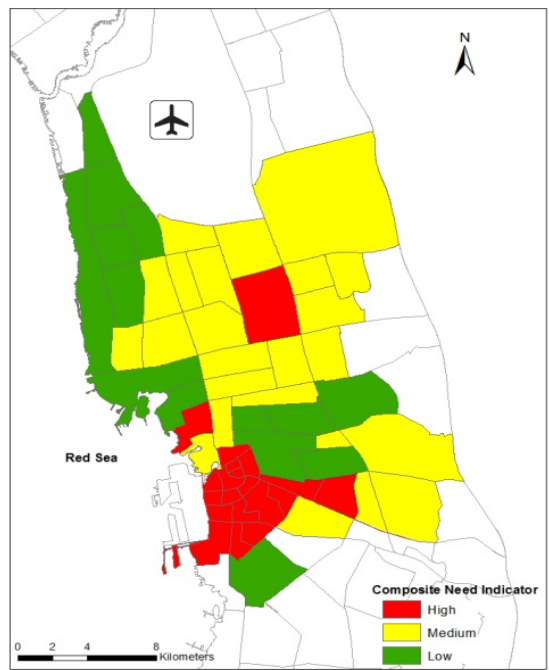

Figure 9: Composite need indicator.

Public transport is important for social inclusion, for providing access to reach activities and services such as work, education, health, shopping and social- 
recreational activities [17]. The provision of public transport depends on demand, which is based on population need. This paper has analyzed the public transport need in Jeddah. This analysis facilitates the identification of potential demand for public transport in Jeddah and assists transportation planners for high social inclusion in planning the routes of public transport system.

\section{Conclusion}

This paper has analyzed the deficiencies of the current public transport system in Jeddah identified potential demand for public transport using GIS based approach. It is found that around $50 \%$ of the Jeddah population have low or no access to the current public transport system, which is characterized, by deficiency and poor condition of the infrastructure, including the buses.

The composite need indicator has shown both a dispersed and clustered patterns of high need for public transport in Jeddah. Districts with high need are concentrated and clustered in the city centre, while single districts are dispersed at the north of the city centre. It was found that a high portion of Jeddah population are in high and medium need for public transport.

The results of this study facilitate the identification of potential demand for public transport in Jeddah and assists transportation planners for high social inclusion in planning the routes of public transport system. Although this study has provided valuable information, it must be noted that available data doesn't cover the entire urban area of Jeddah city. Thus, further studies with the same methodology are highly recommended to include the entire urban area of Jeddah city.

\section{References}

[1] Zhao, P., Sustainable urban expansion and transportation in a growing mega city: consequences of urban sprawl for mobility on the Urban fringe of Beijing, Habitat International 34 (2), pp. 236-243, 2010.

[2] Aljoufie, M., Zuidgeest, M.H.P., Brussel, M.J.G., \& van Maarseveen, M.F.A.M., Spatial-temporal analysis of urban growth and transportation in Jeddah City, Saudi Arabia, Cities, 31, pp. 57-68, 2013.

[3] IBI, Group, Jeddah Public Transport Study, Ministry of Transport, Saudi Arabia, 2007.

[4] Jeddah Municipality, Jeddah strategic plan, Saudi Arabia: Jeddah Municipality, 2009.

[5] Tribby, CP \& Zandbergen, PA, High-resolution spatio-temporal modeling of public transit accessibility, Applied Geography, 34, pp. 345-355, 2012.

[6] Aljoufie, M., Toward integrated land use and transport planning in fast growing cities: case of Jeddah city, Saudi Arabia, Habitat International Journal, 41, pp. 205-215, 2014.

[7] AECOM, Jeddah Spatial Framework Plan In Association With The Jeddah Stormwater Drainage Program, Saudi Arabia: Emirate of Makkah, 2012. 
[8] Althagfy, K., The Existing Public Transportation by Coasters and Limousines in Jeddah City, MSc Thesis, King Abdul-Aziz University, 2003.

[9] Daniels, R. \& Mulley, C., Explaining walking distance to public transport: The dominance of public transport supply, The Journal of Transport and Land Use, 6 (2), pp. 5-20, 2013.

[10] Armstrong Wright, A. \& Thiriez, S., Bus services: reducing costs, raising standards, World Bank Technical Paper 68 (Washington D.C., World Bank, 1987).

[11] Murray, A. T., \& Davis, R., Equity in regional service provision, Journal of Regional Science, 41(4), pp. 577-600, 2001.

[12] Currie, G., Gap analysis of public transport needs: measuring spatial distribution of public transport needs and identifying gaps in the quality of public transport provision, Transportation Research Record: Journal of the Transportation Research Board, 1895, pp. 137-146, 2004.

[13] Currie, G., Quantifying spatial gaps in public transport supply based on social needs, Journal of Transport Geography, 18, pp. 31-41, 2010.

[14] Yao, X., Where are public transit needed-Examining potential demand for public transit for commuting trips, Computers, Environment and Urban Systems, 31(5), pp. 535-550, 2007.

[15] Jeddah Urban Observatory, Districts GIS Indicators, Jeddah Urban Observatory, Jeddah Municipality, 2009.

[16] Jeddah Municipality, Jeddah structure plan, Saudi Arabia: Jeddah Municipality, 2004.

[17] Lucas, K. , Transport and social exclusion: Where are we now?, Paper presented to the 12th World Conference on Transport Research, July 1115, Lisbon, Portugal, 2010 (DOI: 10.1016/j.tranpol.2012.01.013.). 